\title{
Comparison of social studies, Turkish Republic Revolution History and Kemalism, History of Kazakhstan and World History curricula in the secondary education in Turkey and the Republic of Kazakhstan ${ }^{1}$
}

\author{
Lyazzat Beisenbayeva ${ }^{2}$ \\ Yücel Gelişli ${ }^{3}$
}

\begin{abstract}
The aim of this study is to make a comparison between history topics in Social Sciences course, Ataturk's Principles and History of Turkish Revolution course in secondary schools in Turkey and History of Kazakhstan and World History courses in secondary schools in Kazakhstan. This study that has adopted qualitative research methods is a comparative educational research. Data has been collected through data analysis method. In the study, the curriculum of Social Sciences course and Ataturk's Principles and History of Turkish Revolution course in secondary schools in Turkey and the curriculum of History of Kazakhstan and World History courses in secondary schools in Kazakhstan have been compared in terms of objectives, content and weekly course schedule.

Findings show that subject that is based on historical content take place as units in 5th, 6th and 7th grade Social Sciences course. Social Sciences course is three hours per week for 5th and 6th graders. History topics in Social Sciences course include first states in Anatolia, Huns that is the first Turkish state, Turkish states founded in Central Asia, Turks' migration to Anatolia, foundation and development of Ottoman states, science, art and economic structure. Additionally, the rise of Islam, states founded by Muslims, conversion of the Turks to Islam, development of science and art are among the history topics, as well. In 8th grade, for Ataturk's Principles and History of Turkish Revolution course, students attend two hours of lecture per week. This course covers foundation of the Republic of Turkey, Ataturk's life, Ataturk's Principles and political developments of the related period. In Turkish secondary schools, there is not a course on world history. On the other hand, in Kazakhstan, for the History of Kazakhstan, 5th grade students attend one hour of lecture while 6th, 7th and 8th grade students attend two hours of lecture per week. In the curriculum of the History of Kazakhstan, Turkish states founded in Kazakhstan starts with the Sakas and it covers Turkish states in history, their foundation, development and improvements in science, art and economy. Additionally, 6th, 7th and 8th grade students attend one hour of lecture for the World History course. This course includes topics such as states founded in Asia, Europe, America and Africa, foundation and development of Ottoman Empire and the Republic of Turkey that are among states founded by Turks in Anatolia and developments in science, art and economic structure of the related states.
\end{abstract}

Keywords: Social Studies, History, World History, History of Kazakhstan, Lifelong Civic Education

\footnotetext{
${ }^{1}$ This article is the well developed form which was presented in 1st International Conference on Lifelong Education and Leadership for ALL-ICLEL 2015 was occuredin Czech Republic on 29-31 october 2015.

2 Master Degree, Gazi University Education Sciences Institute Ph.D. Student, aishalyaz@mail.ru

${ }^{3}$ Prof..Dr. Gazi University Faculty of Education Department of Educational Sciences, ygelisli@gmail.com
} 
Beisenbayeva, L., Gelisli, Y. (2016). Comparison of social studies, Turkish Republic Revolution History and Kemalism, History of Kazakhstan and World History curricula in the secondary education in Turkey and the Republic of Kazakhstan. International Journal of Human Sciences, 13(1), 532-544. doi:10.14687/ijhs.v13i1.3571

\section{Introduction}

\subsection{History Education in Turkey}

History is a discipline that chronologically examines events that nations have experienced, their political relationships with other societies or nations, their battles, political treaties, migration and cultural lives. Every nation continues to exist through legends, epics or the documents and books by justifying its history. At this point, the discipline of history that we view as national history becomes one of the means for enhancing national identity.

As soon as the Republic of Turkey was founded, important steps were taken in the process of establishing a national state and during the process of transition from understanding of Ummah towards being national citizens with a number of reforms, it was aimed to make education available for all people including both young and elder ones, with the understanding of lifelong learning in formal and non-formal institutions.

However, only after the "Unification Law", was it possible to see revisions in the courses and course content that determine the quality of education. In the first phase, all educational institutions were gathered under one umbrella and transformed into public service institutions that are free for every citizen including children and people beyond school age by being reshaped according to contemporary organization and working order. In the second phase, courses, course schedules, timetables, teaching methods and textbooks have been prepared in accordance with the fundamental principles of the Republic (Aslan, 2012; 334).

After the Republic, efforts were put forth to nationalize education and formal and non-formal education institutions were founded for all people including both young and old people in the country. These nationalization efforts under the patronage of Ataturk were reflected in curriculum, particularly the curriculum of history lesson. Changes in the primary school curriculum in 1924 and 1926 revealed the problem of preparing new course books. For this purpose, the first course books were prepared by Ahmet Refik. "General History" prepared for

$5^{\text {th }}$ grade students in 1924 included the topics of new and modern age. "General History" that he prepared for $4^{\text {th }}$ grade students in 1926 covered the ancient times and middle ages. With the changes made in 1927, new regulations regarding course books and course hours were done based on Turkish history (Öztaş, 2009; 100-101., Çapa, 2002; 47. Bolat, 2012; 237. Aslan,2004; 87-88).

Sometimes it was viewed that history was attributed different missions of other disciplines. It would be proper to examine and evaluate the course of History of Turkish Revolution that was attributed different missions from various disciplines besides understanding of national history within this perspective. There are three essential reasons for the emergence of this discipline:

1.One part of citizenship education

2.One part of the discipline of history

3.A comparative "History of Revolution" at international level (Akt: Aslan,2004; 96).

Making contribution to "citizenship" and "citizenship education" has been an important reason for the emergence of History of Turkish Revolution course. This reveals the idea that courses have social purposes and understanding of history education is based on socialization of students and the necessity to raise good citizens. The process of raising good citizens requires lifelong learning process. Studies were also carried out to this end. Making contributions to students' personality development, socialization and citizenship education by history education has been a goal for every period and in almost every country. Although there have sometimes been criticism of historians about examination of social realities and emphasis on understanding of scientific history, those practices still continue to exist (Aslan, 2004; 96). 
Beisenbayeva, L., Gelisli, Y. (2016). Comparison of social studies, Turkish Republic Revolution History and Kemalism, History of Kazakhstan and World History curricula in the secondary education in Turkey and the Republic of Kazakhstan. International Journal of Human Sciences, 13(1), 532-544. doi:10.14687/ijhs.v13i1.3571

Topics about Republic of Turkish Revolution History and Kemalism that should be given in curriculum and textbooks in primary schools were published in Journal of Announcements on 19th of June 1995. This journal described the topics that will be presented, objectives and behaviors that students should have and explanations regarding examination of subjects. The primary school curriculum developed in 1968 was used without a major change 1995 except for additional units related to Ataturk. Since 1997, the number of primary schools providing eightyear compulsory education increased according to the Basic Law of National Education numbered 1739. That's why, education of social studies in primary schools continued with "national history" and "national geography" courses in $6^{\text {th }}$ and $7^{\text {th }}$ grade and "Republic of Turkish Revolution History and Kemalism" course in $8^{\text {th }}$ grade (Aslan,2004;104). Historical content that was taught as History course in secondary school curriculum since proclamation of the Republic became a part of Social Studies course with the Primary School Curriculum that was piloted in 1962 for the first time.

Social studies education is a course of study formed with an interdisciplinary approach and dates back to 1920s (Yllmaz, Tepebaş, 2011; 158). In the Social Studies curriculum, it is stated that this course is designed to raise effective and responsible citizens in Turkey and the units of this course covers history, geography, economy, sociology, anthropology, psychology, philosophy, social science and political science and law as civics. It is pointed out that teachers need to give lectures by making connections with related topics. While teaching geographical regions, teachers should give examples about the activities in the related regions during Turkish National Struggle, make relations between geography, history and civics and try to help students have national consciousness. Similarly, by using literary works and the written materials (myths, legends, fables, proverbs, folk tales, songs and poems etc.), social studies, literature and geography should be integrated and teach students patriotism (MEB, 2004). It is known that knowledge and skills attained by the end of the course forms basis for individuals' adapting to their environment in their lives.

\subsection{History Education in Kazakhstan}

History education in Kazakhstan should be examined as three periods. Those are period of Tsardom of Russia, the Soviet Union and period after the declaration of independence (Kinac1, 2010). Tsarist administrators could not exactly achieve their goals although Russification efforts through schools such as Russian-Tatar and Russian-Cossack schools founded in Turkish homeland in Tsarist era drew attention (Kinac1, 2010). After the October of 1917, educational institutions were viewed as means for creating a communist society and this was also implemented in Kazakhstan as in other Republics of Soviet Union (Shorish,1991).

During the period of Soviet Union, in a meeting held in the October of 1917, public education commission was founded under the directorate of Lunaçarski. Prominent intellectuals and teachers took decisions and revised curriculum. Under the directorate of Pokrovski, the first example curriculum of history course was developed. During this period, History course was not taught separately and instead of History of Homeland, social studies and labor history courses was given. In this respect, the content of history education was different than Social Studies course (Curasova, 2012).

After the Soviet Union, dependence of history education on imperialism and Russia that was the center of imperialism continued. In Kazakhstan development of historical-methodical ideas and the emergence of books covering historical information influenced history education in Kazakhstan (Curasova, 2012). In 1920s, various researches on teaching social studies were carried out in general despite some inefficiency. A new period started for history education that aimed to teach history separately and new course books were prepared based on the curriculum. However, book writers gave emphasis on social life styles rather than history of homeland. There was not a course that was 
Beisenbayeva, L., Gelisli, Y. (2016). Comparison of social studies, Turkish Republic Revolution History and Kemalism, History of Kazakhstan and World History curricula in the secondary education in Turkey and the Republic of Kazakhstan. International Journal of Human Sciences, 13(1), 532-544. doi:10.14687/ijhs.v13i1.3571

completely composed of history. The decision taken on 5th of September 1930 by the Ministry of Education pointed out that there was necessity for a separate curriculum for history education (Curasova, 2012). This course was rather like social studies course and aimed to help people attain values and attitudes necessary for lifelong learning.

After SSCB's dissolution in 1991 on the basis of the Republics of Soviet Union in accordance with the existing administrative segmentation, "those nations that were designed in weak and imperfect form" regained their independence, but faced with the problems of their nation structure and weaknesses. After Kazakhstan declared its independence in 1991, it proceeded rapidly to become a national state with a set of reforms and various reforms were done in educational institutions and curriculum.

In the period of Soviet Union, there was no national process in history education in schools in Kazakhstan and curriculum determined by the Russian Federation had to be completely implemented. The Republic of Kazakhstan made the law on education in 1992. This law adopted after the independence, this law accepted after the independence contributed to the independency and nationality of history education in Kazakhstan (Curasova, 2012).

It has been one of the major issues on the agenda to investigate and teach the history of Kazakhstan. Some issues are resolved in the various studies and textbooks; however, introduction of important changes and events were not enough after the independence of Kazakhstan (http://ehistory.kz. a)

Since 1989-1990 academic years, the history of Kazakhstan has been started to be taught in Kazakhstan. Since 1991-1992 academic years, the history of Kazakhstan has been taught in the faculty of history in Kazakhstan. The history of Kazakhstan is taught is different educational institutions since 1992. College students had to take a compulsory examination on the history of homeland and this increased the importance of Kazakh history. During the early 1990s, teaching methods, courses, course books were not appropriate for instruction of Kazakh history and experienced historians pointed out this problem via newspapers (http://e-history.kz.b). History curricula were revised after the reforms.

\section{Purpose}

The aim of this study is to make a comparison between history topics in Social Studies course, Turkish Republic Revolution History and Kemalism course in secondary schools in Turkey and History of Kazakhstan and World History courses in secondary schools in Kazakhstan. To this end, courses with historical content were compared in terms of general objectives and content of the courses and common historical topics were determined.

\section{Method}

This study that has adopted qualitative research methods is a comparative educational research. Data has been collected through data analysis method. In the study, the curriculum of Social Studies course and Turkish Republic Revolution History and Kemalism course in secondary schools in Turkey and the curriculum of History of Kazakhstan and World History courses in secondary schools in Kazakhstan have been compared in terms of objectives, content and weekly course schedule. Data has been analyzed and interpreted with the technique of document analysis that is often used in comparative studies as well (Yıldırım \& Şimşek, 2006). 
Beisenbayeva, L., Gelisli, Y. (2016). Comparison of social studies, Turkish Republic Revolution History and Kemalism, History of Kazakhstan and World History curricula in the secondary education in Turkey and the Republic of Kazakhstan. International Journal of Human Sciences, 13(1), 532-544. doi:10.14687/ijhs.v13i1.3571

\section{Findings and Discussion}

History related courses for five, six and seventh grades are among the units of social studies in Turkey. Social Studies Courses for fifth and sixth grade are included in the program three hours a week. In eighth grade, history of Turkish Republic Revolution and Kemalism are studying in the program for two hours a week. While in Kazakhstan, Kazakhstan related history is directly teaching an hour a week for the fifth grade and two hours a week for sixth, seventh and eighth grades. Also world History lessons in secondary school programs are included as one hour per week in the eighth, sixth, seventh grade programs. A comparison of Turkey and Kazakhstan secondary schools History course programs and timetables is given in Table I.

Table 1: A Comparison of Turkey and Kazakhstan Secondary Schools History Course Programs and Timetables

\begin{tabular}{|l|l|l|l|l|}
\hline The name of course & Fifth Grade & Sixth Grade & Seventh Grade & $\begin{array}{l}\text { Eighth } \\
\text { Grade }\end{array}$ \\
\hline Social studies & 3 & 3 & 3 & - \\
\hline $\begin{array}{l}\text { Turkish Republic Revolution History and } \\
\text { Kemalism }\end{array}$ & - & - & - & 2 \\
\hline History of Kazakhstan & 1 & 2 & 2 & 2 \\
\hline World History & & 1 & 1 & 1 \\
\hline
\end{tabular}

According to Table 1 in Turkish secondary schools, courses with historical content included in Social Studies are Ataturk's Principles and Revolution History lessons. Social studies in five, six and seventh grade are carried out three hours a week, and in the eighth grade the history of Republic of Turkish Revolution and Kemalism courses are studied one hour per week. While In Kazakhstan secondary school, Kazakhstan related history courses in fifth, sixth and seventh and eighth grades are accomplished two hours a week and world history course for the seven and eighth grades is carried out one hour per week. A comparison of Turkey and Kazakhstan secondary schools History course purposes is given in Table II.

Table 2: Comparison of History Course Purposes in Turkey and Kazakhstan

\begin{tabular}{|c|c|c|c|}
\hline \multicolumn{2}{|l|}{ Turkey } & \multicolumn{2}{|l|}{ Kazakhstan } \\
\hline $\begin{array}{l}\text { Social studies }(5,6,7 \\
\text { grades) }\end{array}$ & $\begin{array}{l}\text { The history of Turkish } \\
\text { Republic Revolution and } \\
\text { Kemalism (8th grade) }\end{array}$ & $\begin{array}{l}\text { History of Kazakhstan } \\
\text { (5th, 6th, } 7 \text { th and, } 8 \text { th } \\
\text { grades) }\end{array}$ & $\begin{array}{l}\text { World History (5th, 6th, 7th, } \\
\text { and 8th grades) }\end{array}$ \\
\hline 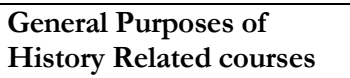 & Gomol D & al Purposes & \\
\hline $\begin{array}{l}\text { 1.Ataturk's principles and } \\
\text { revolutions, understanding } \\
\text { of Turkish Republic social, } \\
\text { cultural and economic } \\
\text { development and its place } \\
\text { in; emphasizing on secular, } \\
\text { democratic, national and } \\
\text { contemporary values. } \\
\text { 2. Grasp the essential } \\
\text { elements and processes that } \\
\text { constitute the Turkish } \\
\text { culture and history, rising } \\
\text { national consciousness to } \\
\text { protect cultural heritage and } \\
\text { accepting the needs to } \\
\text { develop. } \\
\text { 3. Questioning the historical } \\
\text { evidence of different }\end{array}$ & $\begin{array}{l}\text { 1. Ataturk's superior military, } \\
\text { statesmanship and imitating his } \\
\text { revolutionary character. } \\
\text { 2. Understanding of Turkish } \\
\text { National Struggle, the Turkish } \\
\text { national freedom, independence, } \\
\text { patriotism, and national unity and } \\
\text { understanding Turkish ability to } \\
\text { overcome in the case of } \\
\text { difficulty, 3. Understanding the } \\
\text { sense of history and the } \\
\text { importance of Turkish } \\
\text { Revolution under the effect of } \\
\text { Ataturk leadership, } \\
\text { 4. Understanding Turkish } \\
\text { National Struggle and Revolution, } \\
\text { and its international specifications } \\
\text { as exemplary between other }\end{array}$ & $\begin{array}{l}\text { Regarding students' } \\
\text { knowledge and level of } \\
\text { preparation, and taking } \\
\text { into account age } \\
\text { differences, give the clear } \\
\text { history of Kazakhstan } \\
\text { from earliest times to the } \\
\text { present, This general } \\
\text { purpose is expected to } \\
\text { achieve the objectives and } \\
\text { give a full-fledged } \\
\text { systematic information } \\
\text { about the history of } \\
\text { Kazakhstan. } \\
\text { 1. Give students fully and } \\
\text { systematic information } \\
\text { about the history of } \\
\text { Kazakhstan }\end{array}$ & $\begin{array}{l}\text { 1. Aims to achieve the objectives } \\
\text { of program, to give systematic } \\
\text { information about important } \\
\text { events in human history, from } \\
\text { ancient times up to now. } \\
\text { 1. Provide systematic } \\
\text { information about important } \\
\text { events and changes on world } \\
\text { history, their connections and } \\
\text { chronology. } \\
\text { 2. Under the existing } \\
\text { framework of history } \\
\text { development give information } \\
\text { about importance of values } \\
\text { such as civil, religious and } \\
\text { national traditions; } \\
\text { 3. Develop the ability to apply }\end{array}$ \\
\hline
\end{tabular}


Beisenbayeva, L., Gelisli, Y. (2016). Comparison of social studies, Turkish Republic Revolution History and Kemalism, History of Kazakhstan and World History curricula in the secondary education in Turkey and the Republic of Kazakhstan. International Journal of Human Sciences, 13(1), 532-544. doi:10.14687/ijhs.v13i1.3571

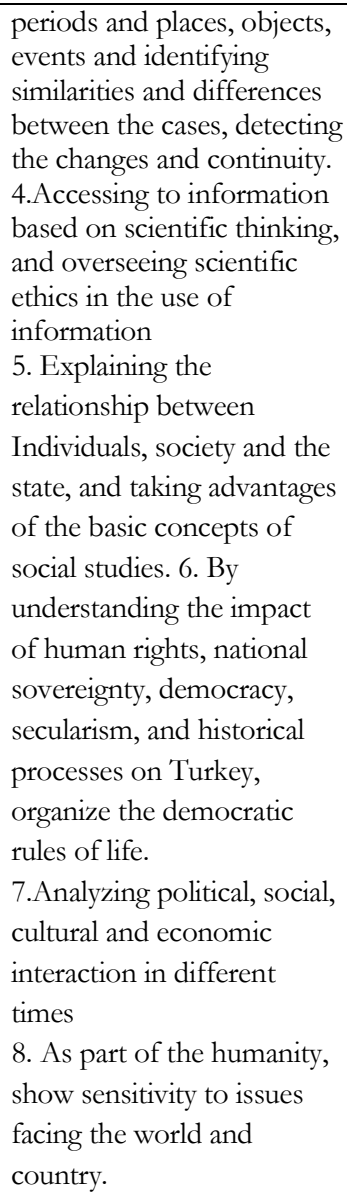

7.Analyzing political, social, cultural and economic interaction in different times

8. As part of the humanity, show sensitivity to issues facing the world and country.
nations,
5. Understanding the expressions of Human rights, national sovereignty, nationalism, democracy, modernity, secularism and the concept of republic for the Turkish nation and organize their lives according to democratic rules,
6. Understanding of Ataturk's principles and revolutions of the Republic of Turkey, its social cultural and economic development; and underlying its secular, democratic and modern values,
7. To Love the country as citizens of the Republic of Turkey and know the rights and fulfill the your responsibility as a citizen to keep up with national consciousness, 8.Realizing the Republic of Turkey as an indivisible whole with its territory and nation and basing its dynamic basis on Ataturk's principles and revolutions, 9.Assessing Turkey's geopolitical importance in terms of the regional and global effects and to be sensitive to internal and external threats,
10. Rising the consciousness of humanity as being the member of the country and show sensitivity to the issues facing the world and Turkish nation.

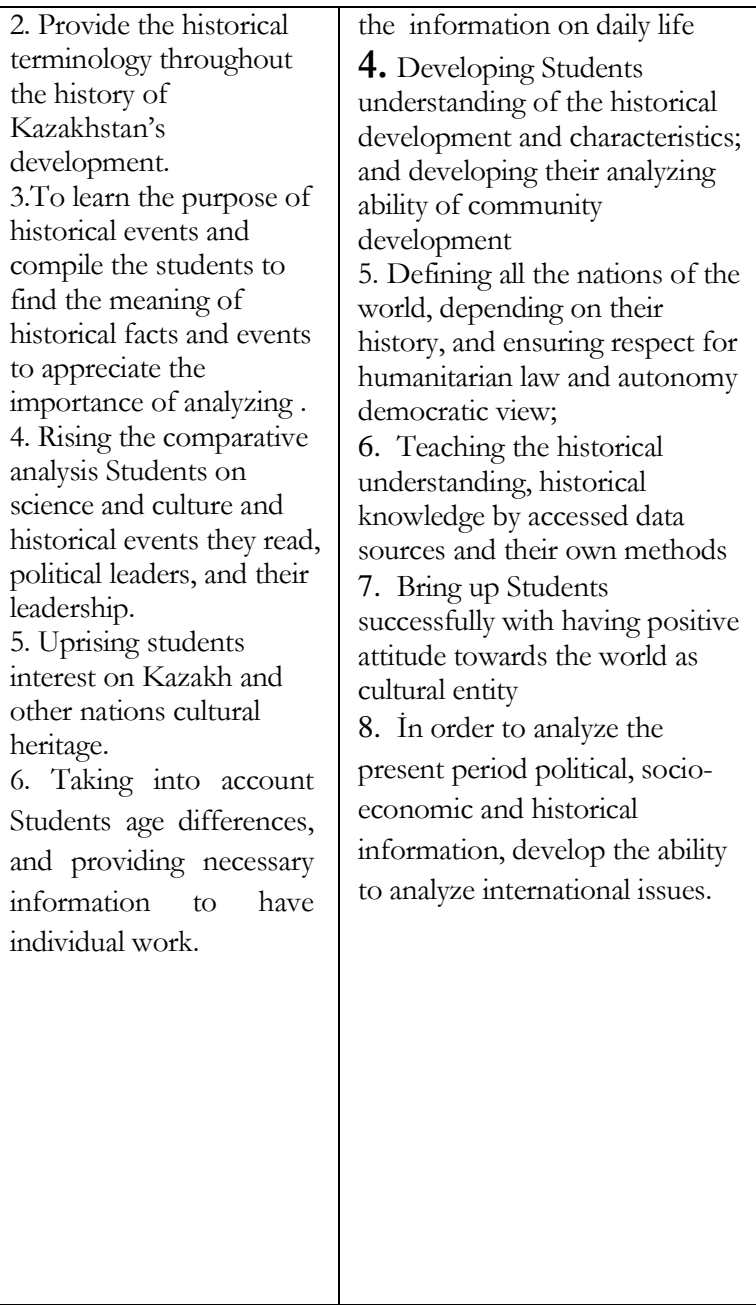

2. Provide the historical terminology throughout the history of

development.

3.To learn the purpose of orical events and find the meaning of 4. Rising the comparative analysis Students on science and culture and political leaders, and their leadership.

. Uprising student 6. Taking into accoun information to have individual work.

\begin{abstract}
4. Developing Students understanding of the historical and developing their analyzing ability of community evelopment world, depending on their democratic view; knowledge by accessed data Bes and their own methods attitude towards the world as present period political, sociopic and historical

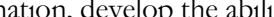
.

In secondary schools of Turkey, the overall objectives of social studies for fifth, sixth and seventh grades are written jointly. In order to achieve this overall objective, the gains are specified in each grade (class) unit. Examining the history related content of secondary schools course program will represent the fundamental characteristics of the Turkish National Education and it aims to bring up individuals in line with its objectives. Also the general objective of program is to help to the development of the Republic of Turkey, to improve individuals with relying on Ataturk's principles and to equip individuals with civilizations living in Anatolia and Central Asia. World history is studying at secondary school program of Turkey. Unlike Turkey, Kazakhstan has created courses directly with the name of Kazakhstan history; which is directly considering, the establishment and development of the Kazakh state, Kazakh leaders and scientists who take part to bring the development in the Kazakh culture. The purposes which are applied in the course although not directly involved can raise Kazak's children national identity and culture.

With studying world history students as well as learning about the development of the world's nations, they will be respectful to other societies' cultures and traditions, and be able to use the historical method to analyze current events. Unlike Turkey in Kazakhstan, course programs are equipped with both national and local dimensions. Examination of objectives in curriculum of both countries reveals that the aim is to give students knowledge and skills that they will use in a lifetime and to develop learners' methodological knowledge that they will use to find necessary knowledge and skills. Table 3 shows the comparison of fifth grade history related courses in Turkey and Kazakhstan. 
Beisenbayeva, L., Gelisli, Y. (2016). Comparison of social studies, Turkish Republic Revolution History and Kemalism, History of Kazakhstan and World History curricula in the secondary education in Turkey and the Republic of Kazakhstan. International Journal of Human Sciences, 13(1), 532-544. doi:10.14687/ijhs.v13i1.3571

Table 3: The Comparison of Fifth Grade History Related Courses in Turkey and Kazakhstan

\begin{tabular}{|l|l|l|}
\hline Turkey & Kazakhstan \\
\hline Social Studies Units & Kazakhstan History Departments & World History Departments \\
\hline Unit 1. I Learn My Rights & Part I .The World History & No world history in fifth grade \\
Unit 2. Step By Step Turkey & Part I I. The Travel History & \\
Unit 3. Getting To Know Our Regions & Part III. Kazakhstan's Merging in & \\
Unit 4. What We Produce & Russia & \\
Unit 5. True Dreams & Part IV. In the World of Beauty & \\
Unit 6. Employees Of Society & Part IV. Kazakhstan in XX. Century & \\
Unit 7. One Country One Flag & & \\
Unit 8. All Of Our World & & \\
\hline
\end{tabular}

As it is shown in Table 3, Turkish related history has been involved as units in 5th Grade Social Studies Course. Historical subjects in the fifth grade were created thematically. "Step by step Turkey" unit provide information about the life of Ataturk, Ataturk's principles and reforms, government structure and management system of the Republic of Turkey as unity. Historical topics in the fifth grade are limited to two units.

In Kazakhstan, history related topics of the fifth grade content are directly included Kazakhstan history. In Kazakhstan, "Kazakhstan history" lesson book, the first people who were living in the territory of Kazakhstan until to be as an independent state is given with the understanding of nationalisms. If we focus on the content of the two courses, we will see that program aims to provide the basic ideology of the state. Table 4 represents Content Comparison of the Sixth Grade Level in Turkey and Kazakhstan.

Table 4: Content Comparison of the Sixth Grade Level in Turkey and Kazakhstan

\begin{tabular}{|l|l|l|}
\hline Turkey & KAZAKHSTAN \\
\hline $\begin{array}{l}\text { SOCIAL STUDIES UNIT AND } \\
\text { ISSUES }\end{array}$ & KAZAKHSTAN HISTORY RELATED TOPICS & $\begin{array}{l}\text { WORLD HISTORY } \\
\text { RELATED TOPICS }\end{array}$ \\
\hline Unit 1. Learn Social Studies Unit & Introduction & Introduction \\
\hline Unit 2. Life on Earth & Part I. Life Of Old People. & Part I. Old Rivers States \\
Unit 3. Settlement from the past to & Part II. Agriculture And Livestock Development Part & Part II. Ancient Egypt \\
the Present & III. Bronze Age & \\
Unit 4. Turks on the Silk Road & Part IV. Kazakhstan In The Early Iron Age, \\
Unit 5. The homeland of Anatolia & Part V. Early Iron Age Societies Living In & \\
Unit 6. Our Country and The World & Kazakhstan Territory, & \\
Unit 7. Democracy Adventure & Part VI. Kazakhstan Territory In The Early Iron Age, & \\
Unit 8. Electronic Century & Part VI I. Kazakhstan's Nomadic, Marital Success & \\
& (Development) & \\
\hline
\end{tabular}

As it is shown in Table 4 history related topics of Turkey has been involved in the units of 6th Grade Social Studies Course. History related topics in sixth grade have been created thematically. Ataturk and Social Studies subject begins with the first unit. In considering Life settlement on Earth from past to now, the past civilizations living in Africa and the polar and America regions after that the civilizations in Anatolia have been involved in the course content. The topics related to Turkish History consider "Turks on the Silk Road to Anatolia as Homeland".

This unit is starting with Hunan as the first Turkish state and is considering Göktürks; it deals with the history of the Uighurs, Orkhon inscriptions and the Turks joining the regular army and its 
Beisenbayeva, L., Gelisli, Y. (2016). Comparison of social studies, Turkish Republic Revolution History and Kemalism, History of Kazakhstan and World History curricula in the secondary education in Turkey and the Republic of Kazakhstan. International Journal of Human Sciences, 13(1), 532-544. doi:10.14687/ijhs.v13i1.3571

development up to now, and the importance of the Silk Road. Once again, this unit deals with the emergence of the Islam, Prophet Mohammed and the four Abbasid Caliphs and Umayyad period. Moreover, the first Turkish Muslim state Karahans, Gazneliler and the development of the Seljuks, Turkish culture, the development of architecture and art, and the life story of scientists are considered.

In the unit related to the Adventure of democracy, the form of government and the contribution of historical knowledge to the development of democracy, the document, sermons and declarations are considered. Taking into account all items, Hamurabi Act, the Prophet Muhammad's farewell sermon, the American Declaration of Independence, Laws of Sultan Suleiman the Magnificent, the first Turkish and Ottoman Constitution and Declaration of Human Rights are universal samples. In History Courses of the $6^{\text {th }}$ grade of Kazakhstan secondary school, the first Stone Age living people in the territory of Kazakhstan and the features of the every period first living community are given.

Saga state is adopted as the first emerged Turkish state in Kazakhstan, its state structure, properties, culture and development has been considered in large, then the Huns, the organization development of the Huns, the westward migration, Hunan culture, the Contribution of gypsies culture to the World, Runic Articles, Bilge Khan, Tonyukuk inscriptions have also been given.

In secondary schools of Kazakhstan in the sixth grade between world history course topics, Information about the history of the Old World, Old World History Processes, the Place of Old World History in the Universe history, the Sumerian and Akkadian state which were founded in the Old Double rivers, ancient Babylon, the rise of Babylon, its entity as being the cultural center, the laws of Hammurabi, the emergence of literature, architecture, art, The first calendar, religion; Egyptian civilization and its establishment, the emergence of the states, the Egyptian pharaohs and social life issues in Egypt are considered. When examining the history topics of Sixth grade history subjects in Kazakhstan and Turkey, there will be common issues.

In Turkey's Social Studies course, the first place between established Turkish states is given to Hunan while in Kazakhstan History lessons the Saga has been recognized as the first Turkish established state. Both countries established the starting point from the date that the issue has been addressed in their countries.

Also between Social studies topics, Göktürk and Uygurs of Central Asia are represented. The emergence of Islam, the first Muslim state, the acceptance of Islam in Turkey and the first Muslim Turkish states are also referred in the program. The Sumerians and the Babylonians which are pointed out in World History course are among the topics of Social Studies. The fifth table shows the comparison of Turkey and Kazakhstan Seventh Grade history related courses.

Table 5: The Comparison of Turkey and Kazakhstan Seventh Grade History Related Courses

\begin{tabular}{|c|c|c|}
\hline TURKEY & KAZAKHSTAN & \\
\hline $\begin{array}{l}\text { SOCIAL STUDIES UNIT AND } \\
\text { TOPICS }\end{array}$ & KAZAKHSTAN HISTORY LESSON TOPICS & $\begin{array}{l}\text { WORLD HISTORY COURSE } \\
\text { TOPICS }\end{array}$ \\
\hline $\begin{array}{l}\text { Unit 1: Communication and } \\
\text { Human Relations } \\
\text { Unit 2: our country Population } \\
\text { Unit } 3 \text { The Journey in Turkish History: } \\
\text { Anatolia the Turkish New land } \\
\text { Unit } 4 \text {. The Science in time } \\
\text { Unit } 5 \text { Economics and Social Life } \\
\text { Unit } 6 \text { Living Democracy }\end{array}$ & $\begin{array}{l}\text { Introduction: } \\
\text { Part I. Description of the cycle, Midcentury definition, } \\
\text { Mid Century times. } \\
\text { Part II. Kazakhstan in } \\
\text { The mid centuries old (medieval) } \\
\text { Part III. Early Middle Centennial State in the territory } \\
\text { of Kazakhstan. } \\
\text { Part IV. Local and migrant culture in the VI }\end{array}$ & $\begin{array}{l}\text { PART I: Past Centuries } \\
\text { Western and Central Europe in V-X } \\
\text { centuries } \\
\text { Byzantine in V-X. Centuries in the Near } \\
\text { East, Central Asia and Russia } \\
\text { Characteristics of social community in the } \\
\text { Middle Centuries } \\
\text { Part II. Advanced Mid-century's }\end{array}$ \\
\hline
\end{tabular}


Beisenbayeva, L., Gelisli, Y. (2016). Comparison of social studies, Turkish Republic Revolution History and Kemalism, History of Kazakhstan and World History curricula in the secondary education in Turkey and the Republic of Kazakhstan. International Journal of Human Sciences, 13(1), 532-544. doi:10.14687/ijhs.v13i1.3571

\begin{tabular}{|c|c|c|}
\hline $\begin{array}{l}\text { Unit 7. Bridges Between Countries Unit } \\
\text { 8. "World" War }\end{array}$ & $\begin{array}{l}\text { - IX centuries } \\
\text { Part VI. Kazakhstan in Mid-Century Part VII. } \\
\text { Establishment of the new State in the territory of } \\
\text { Kazakhstan in the Mid } \\
\text { Century } \\
\text { Part VIII. Great Silk Road in Kazakhstan territory } \\
\text { Part IX Kazakhstan civilization at the beginning of X - } \\
\text { XIII century } \\
\text { Part X. Kazakhstan in First Half of XIII - } \\
\text { XV Century } \\
\text { Part XI. Kazakhstan Ethnic Processes between XIV - } \\
\text { XV centuries. Emergence of the Kazakh Nation } \\
\text { Part XII. Kazakhstan Culture in XIV - XV centuries } \\
\text { Part XIII. Kazakhstan in late midcenturies. } \\
\text { The establishment of State } \\
\text { Part XIV.. Establishment of the Kazakh } \\
\text { National State } \\
\text { Section XV. The Development of the } \\
\text { Kazakh between XVI and XVII centuries Part XVI. } \\
\text { Kazakh Social -Economic developments between XV- } \\
\text { XVII centuries Part XVII. Kazakhstan in second half } \\
\text { of } \\
\text { XVII Century } \\
\text { Section xvil. Kazakhstan in XVI - XVII centuries }\end{array}$ & $\begin{array}{l}\text { European States in XI-XV century } \\
\text { Peoples Christian Church, in XI-XIII } \\
\text { centuries, the Crusader Wars } \\
\text { South Peoples exiting of feudal state } \\
\text { Central Asia and Africa Peoples between } \\
\text { XI-X centuries } \\
\text { The revolt against the Mongol-Tatars } \\
\text { people } \\
\text { Part III. The late midcentury } \\
\text { XVI-XVII European States in XVI-XVII } \\
\text { century's Russian territory merging and the } \\
\text { collapse of the Golden Order (XV-XVI } \\
\text { The end of XV. Century and the } \\
\text { Civilizations of the European People at the } \\
\text { beginning of XVII. century }\end{array}$ \\
\hline
\end{tabular}

As it is shown in table 5 Turkish History related subject for the 7th Grade are represented as units in Social Studies Course. They are appeared in $7^{\text {th }}$ grade thematically.

In the unit related to the Turkish History Journey (third unit), the Anatolia as new land of Turks, is given as same title, the establishment of Anatolian Seljuk Empire, the event of period and the fall of Seljuks, establishment and spread of the Ottoman Empire, the rising period until the Tulip period are considered.

In the fourth, studying on Science Development is discussed, the first civilizations in Anatolia, the invention of writing and the use of ancient Sumerian, Hittite, type of the Egypt Phoenician, Turkish and Islamic states Scholars, such as Ibn Sina, Khwarizmi, etc., the development of geographical discoveries science in the world, the Renaissance, the Reformation, the Enlightenment Age, Industrial Revolution, the development of freedom of thought and science are discussed. In the sixth unit, historical development of democracy in Turkey from past up to now, the nature of the Republic of Turkey, in the seventh unit "the bridge between the countries" the last period of the Ottoman Empire, Canakkale and the first world wars are also discussed.

In the Seventh Grade history related issues of Social Studies course, the Turkish Anatolian Seljuk and Ottoman Empire's establishment, development and their fall and Turkey's development issues in Science art are included. With regarding the science and art development in the world, the industrial revolution subjects are given in the context.

Seventh Grade of Kazakhstan is classified according to developments in the centuries, started from the Middle Ages, then discussed the Middle Ages and its characteristics after that the description of regions in the territory of Kazakhstan, and the development of the state which was established in this region; also development of the social and cultural lives are considered. In the first part, Kazakhstan in the old medieval, and the states that emerged in the territory of Kazakhstan are discussed. The establishment of the Göktürk Khanate (land and culture), Türgeş Khanate, life and civilization, the establishment of Karluk state culture, the rise of the Turkish writing, the division of the Khanate, the establishment of Oguz state (residential area of Oguz tribes, social structure, ethnic status), Oguz in Kazakhstan territory, their lifestyle, arts and crafts, the destruction of the 
Beisenbayeva, L., Gelisli, Y. (2016). Comparison of social studies, Turkish Republic Revolution History and Kemalism, History of Kazakhstan and World History curricula in the secondary education in Turkey and the Republic of Kazakhstan. International Journal of Human Sciences, 13(1), 532-544. doi:10.14687/ijhs.v13i1.3571

Oguz state, the establishment of the Kimak state, social and political situation of the Khanate, the effect of ethnic and tribal institutions on them,

the destruction of the Kimak state; the local and nomadic culture between VI - IX centuries, their influence on each other, cities and residential areas, city buildings (tombs, mosques), handicrafts (ceramics making, metallurgy, metal resources), trade, monetary accumulation, architecture and art, folk verbal literature, writing and religion (language and writing, old song writing, Arabic script), religious beliefs; Kazakhstan in Midcentury, the establishment of new states in the territory of Kazakhstan in Central mid century, Karahanit, the establishment of the state, Khanate's acceptance of Islam, organizations of Kipchak state; Social and political situation in Kazakhstan in the middle ages, ethnic backgrounds are discussed. In this chapter the emergence of the Silk Road in Kazakhstan territory and development of economy and trade in the cities that are settled in caravan routes are considered. The chapter related to the development of Kazakhstan civilization, the city development in central Asia, religion, cultural beliefs, the effect of Kazakh culture and science, the Islamic religion and Arab writing, science, the development of civilization and science and the life of important scientists of the era are considered from the beginning of X - XIII centuries. Farabi, Biruni, Kashgar, Mahmut, Yusuf Hassan, Ahmed Yesevi,and Hacip are the examples of theses century. At the first half of XIII - XV century, the Mongol Empire, the Golden Horde's organization; the gain freedom by Ak Orda, Mongolia; Topal Timur state; Nogai Army, the khanate of Abilhay are discussed. The process of Kazakhs ethnic in Kazakhstan

between XIV - XV centuries, the emergence of nation and ethnic development are considered. the Kazakhstan culture in XIV - XV centuries, the Kazakhstan in the late mid-century, the State's establishment, the establishment of the Kazakh national state, the development and strengthening of Kazakh state between XVI - XVII centuries, social-economic development of the Kazakh khanate between XV-XVII centuries, Kazakhstan in the second half of XVII century, the Kazakh khanate loss of power, Kazakhstan in XVI - XVII centuries, folk culture, traditional works of Kazakh people, Kazakh folklore, history and literature are discussed.

In Seventh Grade World History course Part I: Western and Central European states, Germany and France in

V-X centuries, Byzantine, the Near East states, Central Asia and Russia in the V-X. Centuries, , Byzantine Empire in the V-X centuries, , the Arabs, the development of the Islamic world civilization in VI-X centuries, feudal relations in Central Asian territory in Mid Century, the Slavs in middle ages, the establishment of Russian Knezlig, the social structure of the state which was founded in the middle centuries and community characteristics, feudal structures; Section II: Advanced Middle Ages, the European States between X -XVI centuries, Christian Church in XIXIII centuries, the Crusades wars, the fall and rise of South and East Asian feudal states, MongolTatar Uprising, Central Asia and Africa Peoples between XI-XV centuries Section III. Last Middle Ages, European States in XVI-XVII centuries, the end of Russian territory merging and the fall of Golden Army (XV-XVI a.) the end of XV. Century, European civilization in the first half XVII century, are broadly included in the program. In Seventh Grade established states in Europe and Asia, are discussed with considering event consequences and development period, also Renaissance and Reformation which are appeared in the Europe, science and industry development have been included in the program. Ottoman state in developed mid-century, establishment and development, culture and civilization, and Khorezm are discussed in course program.

Ottoman culture and civilization were also among seventh grade World History topics. Anatolian Turkish history has been separated from Kazak's history. Courses related to the history of Kazakhstan have considered separately than Turkish history, it is involved in the program as 
Beisenbayeva, L., Gelisli, Y. (2016). Comparison of social studies, Turkish Republic Revolution History and Kemalism, History of Kazakhstan and World History curricula in the secondary education in Turkey and the Republic of Kazakhstan. International Journal of Human Sciences, 13(1), 532-544. doi:10.14687/ijhs.v13i1.3571

General Turkish History. Table 6 shows the comparison of Turkey and Kazakhstan eighth grade history course program contents.

Table 6: The Comparison of Turkey and Kazakhstan Eighth Grade History Course program Contents

\begin{tabular}{|c|c|c|}
\hline TURKEY & KAZAKHSTAN & \\
\hline $\begin{array}{l}\text { The History of Turkish Republic } \\
\text { Revolution and Kemalism }\end{array}$ & $\begin{array}{l}\text { KAZAKHSTAN HISTORY COURSE } \\
\text { TOPICS }\end{array}$ & $\begin{array}{l}\text { WORLD HISTORY COURSE } \\
\text { TOPICS }\end{array}$ \\
\hline $\begin{array}{l}\text { Unit 1: Mustafa Kemal from } 1881 \text { to } \\
1919 \\
\text { Unit 2. Preparation of National } \\
\text { Struggle Period } \\
\text { Unit } 3 \text { Fronts in the War of } \\
\text { Independence } \\
\text { Unit } 4 \text { Turkish Revolution Unit } \\
5 \text { Kemalism and Ataturk's } \\
\text { principles } \\
\text { Unit } 6 \text { Ataturk Period Turkish Foreign } \\
\text { Policy } \\
\text { Unit 7. Ataturk's Death }\end{array}$ & $\begin{array}{l}\text { Part I. Kazakhstan Social-Economic, Social } \\
\text { and Cultural Developments in XVIII Part II. } \\
\text { Social-economic and political condition in } \\
\text { Kazakhstan at the first half of } \\
\text { XIX } \\
\text { Part III. Forced Participation of Kazakhstan in } \\
\text { Russia and the End of Kazakh Khanate } \\
\text { Empire } \\
\text { Part IV. Kazak's Traditional Civilization and } \\
\text { Lifestyle at the first half of XIX Part V. } \\
\text { Social, Economic and Political condition in } \\
\text { Kazakhstan at second half of } \\
\text { XIX. Century } \\
\text { Part VI. Kazakhstan at the beginning of XX. } \\
\text { Century } \\
\text { Part VII. Kazahkistan'at the second half of XIX } \\
\text { and its cultural life at the beginning of XX }\end{array}$ & $\begin{array}{l}\text { Part I. World in XVI-XVIII. centuries } \\
\text { Part II. The world at the beginning } \\
\text { XIX -XX centuries. }\end{array}$ \\
\hline
\end{tabular}

In the eighth grade of the Republic of Turkey in secondary schools, Turkey's Revolution History and Kemalism lesson are taught. Topics are based on the establishment of the Republic of Turkey, Ataturk's life, the fundamental characteristics of the Republic of Turkey, Ataturk's principles and revolutions, and Ataturk period Turkish foreign policy.

In Kazakhstan, Kazakhstan History lessons from eighteenth century to the twentieth century the historic developments of Kazakhstan are considered according to the centuries. The first section considers Kazakhstan social-economic, political and cultural development, relations with Russia, the struggle of Kazakh National Uprising, during this period in the development of science and civilization in the XVII century. Second section discuss the social-economic and political situation in Kazakhstan, Bökey khanate, Russian Relations with the Kazaks, the end of the Khanate period in Kazakhstan, the starting of public independence movement by İsatay Taymanul and Mahembet Ötemisul, the colonial period, starting national struggle movement of Kenesar the Kasimul in the 1837-1847 as events of First Half of XIX Century are discussed. In Section III the Force Participation of Kazakhstan in the Russian Empire and the end of Kazak's Khanate are processed. This section is mainly focus on the Force Participation of Kazakhstan in the Russian Empire Kazakh's war against Central Asia and tsarist government; in the fourth chapter, the Kazak's traditional culture and lifestyle issues, the Kazakh national holiday and traditional lifestyles at the beginning of XIX are discussed. At the fifth section, the XIX century second half, Kazakhstan's social economic and political situation, the established reforms, the placement of Russian to Kazakh territory, immigration policies of the tsarist government, the status of city in Kazakhstan, the development of the industry, the migration of Uighur and Dungan to Yedisu, emergence of different ethnicities in Kazakhstan and establishment of Kazakhstan Diaspora abroad are considered. In the VI section, Kazakhstan at the beginning of XX century, uprising of Kazakhstan 
Beisenbayeva, L., Gelisli, Y. (2016). Comparison of social studies, Turkish Republic Revolution History and Kemalism, History of Kazakhstan and World History curricula in the secondary education in Turkey and the Republic of Kazakhstan. International Journal of Human Sciences, 13(1), 532-544. doi:10.14687/ijhs.v13i1.3571

during Russian revolution is considered. In section VII Kazakhstan at the second half of XIX century, and at the XX century its Cultural life, education, educators life (Ibiray Altinsarin), the most important science centers and scientists, Kazakh musical art, Kazakhstan's religious policies in the Tsarist period are referred. This course is completely devoted to the historical development in Kazakhstan.

In first and second sections of Eighth Grade World History course, between the XVII-XX centuries' topics, the development of capitalism in England, the French Revolution, Russia, and developments in North America, also developments in training and teaching in the eighteenth century are discussed. Also in this section developments in Asia and Africa are discussed. Again, from the seventeenth century, the Ottoman state development issue is between the main topics of social studies course.

\section{Conclusions And Suggestions}

According to research findings; history related content in fifth, sixth and seventh grades of Turkey are among the units of social studies. Social Studies Course in the fifth and sixth grades program is included three hours a week. Course topics include the history of the Social Studies; the first established state in Anatolia, the first Turkish state established by the Turks which is initiated from the Huns in Central Asia (the first Turkish state) and migration of Turks in Anatolia, the Seljuks and the establishment and development of the Ottoman Empire, science, art and economic structure are considered. In addition to, the rise of Islamic state established by the Muslims, the encounter with the Turks and Islam, development of science and the arts are pointed out in the course. In eighth grade class, the Republic of Turkey Revolution History and Kemalism are included in the program as two hours a week. This course covers the establishment of the Republic of Turkey, Ataturk's life; Ataturk Revolution and the political development era. Course of world history in secondary school are not covered by the program in Turkey. The course contents and subjects in secondary school program mostly deal with Turkish history, civilization in Anatolia and the history of Islam. It is less included the World History related topics. While in Kazakhstan the history of Kazakhstan is directly taught one hour per week in the fifth, six and seven grades, and two-hour a week in eighth grade.

In Kazakhstan History course program, Turkish states established in the territory of Kazakhstan, starting from Sakai to the present day are considered and development of the states, science, art, and the developments in the economic structure are discussed. However, this course is considering the establishment of the khanate period in Kazakhstan state and its occupation with Tsarist Russia and the incidents that occurred during that period are discussed. World History lessons in secondary school programs is taught in sixth, seventh, and eighth grades one hour per week. In the world history course program, Asia, Europe, America and the state established in Africa, and the established states by Turks in Anatolia Ottoman Empire and the establishment and the development of the Republic of Turkey, science, arts and economic structure are considered in course contents.

\section{References}

Aldabek N, Bekiş R, Kojahmetoğlu K., Makaşeva K., Bayzakova K. 2012. 8 sinıf Dünya tarihi ders kitabı (16401914), Almatı, Mektep. Bağımsız kazakistan tarihine ilişkin metinler. Retrieved: 13.09.2015 from http://ehistory.kz/(a)kz/contents/view/1731

Aslan B 2004. Türkiye'de milli tarih anlayışı bağlamında dünden bugüne inkılap tarihi dersleri, Karabekir Ë̈itim Fakültesi Dergisi, 9: 81-109. 
Beisenbayeva, L., Gelisli, Y. (2016). Comparison of social studies, Turkish Republic Revolution History and Kemalism, History of Kazakhstan and World History curricula in the secondary education in Turkey and the Republic of Kazakhstan. International Journal of Human Sciences, 13(1), 532-544. doi:10.14687/ijhs.v13i1.3571

Aslan E 2012. Atatürk Döneminde Tarih Eğitimi- I: “Türk Tarih Tezi” Öncesi Dönem (19231931). Eğitim ve Bilim, 37(164):332-346.

Bolat BS 2012.Tanzimat'tan demokrat parti ye kültür politikaları ve tarih anlayışları. The Journal of Academic Social Science Studies, 5(8):231-247.

Curasova AŞ 2012.Tarih Öğretim Yöntemi, Batı Kazakistan Devlet Üniversitesi Basımevi. Oral.

Çapa M 2002. Cumhuriyet'in ilk yıllarında tarih öğretimi, Ankara Üniversitesi Türk İnkılâp Tarihi Enstitüsü, Atatürk Yolu Dergisi, 29-30: 39-55.

Kabildinov ZE, Kayıpbayeva AT 2012. XVIII Asır - 1914 y1l genel ortaokulların 8. sinıf Kazakistan tarihi ders kitabı. Kazakistan Cumburiyeti İlim ve Bilim Bakanluğ. Almat1 (Atamura).

Kayalı H 2004. İlköğretim okullarında 6. sınıf sosyal bilgiler dersi coğrafya konularının öğrenilmesi ve öğretilmesinde etkili olan faktörler, M.Ü. Atatürk Eğitim Fakültesi Eğitim Bilimleri Dergisi, 20: 101-114 KAZAKISTAN EĞITIM VE BILIM BAKANLIĞI 2013a. Kazakistan Taribi Dersi Ögretim Programı, Astana.

KAZAKISTAN EĞITIM VE BILIM BAKANLIĞI 2013b. Dünya Taribi Dersi Öğretim Program, Astana.

Kınac1 C 2010. Sovyetlerden günümüze Kazakistan'da Kazak dilinde eğitim politikaları, Turkish Studies International Periodical For the Languages, 5(4): 1304-1319.

Maşimbayev S, Tortayev S, Macenova M, Tkaçenko V 2012. 7.sınıf orta asırlardaki dünya tarihi, Kazakistan Cumburiyeti İlim ve Bilim Bakanliğ, Almatı «Atamura».

MEB 2004. 4 ve 5. Sinıf Sosyal Bilgiler Ders programı, (karar tarihi 12.7.2004). Retreived 8 September from http://ttkb.meb.gov.tr/

MEB 2014a. İlköğretim 5.sınıf sosyal bilgiler ders kitabı. Milli Ĕgitim Bakanlğg Yayıları. Ankara

MEB 2014b. İlköğretim 6.sınıf sosyal bilgiler ders kitabı. Milli Eğitim Bakanlı̆̆ı Yayınlar. Ankara

MEB 2014c. İlköğretim 5.sınıf sosyal bilgiler ders kitabı. Milli Eğitim Bakanlĭg Yayınlar. Ankara

MEB 2014d. Türkiye cumhuriyeti inkilap tarihi ve Atatürkçülük. Milli Eğitim Bakanlğı Yayınlar. Ankara

Öztaş S 2009. Atatürk dönemi tarih anlayışı ve tarih öğretimi, Adiyaman Üniversitesi Sosyal Bilimler Enstitüiü Dergisi, 2: 94-107.

Shorish MM 1991. Sömürgecilik ve eğitim, Sovyetler Birliğinde etnik azinliklarin eğitimi(Haz: Philip G. Altbach Gail P. Kelly, Çev: İbrahim Kalın), İnsan Yayınları, İstanbul.

ULUSAL SOSYAL BİLĠLER EĞİTiMi ÇALIŞTAYI. (2012). Sonuç Bildirgesi (14-16 Aralık 2012), Gariantep Üniversitesi. Gaziantep.

Yıldırım A, Şimşek H 2006. Sosyal bilimlerde nitel araştırma yöntemleri, Ankara: Seçkin Yayınları.

Yılmaz K 2010. Sosyal bilgiler eğitimindeki sorunlar ve çözüm önerileri: öğretim elemanlarının görüşleri, Türk Eğitim Bilimleri Dergisi, 8(4): 839-867.

Yılmaz K., Tepebaş F 2011. İlköğretim düzeyinde sosyal bilgiler eğitiminde karşılaşılan sorunlar: mesleğine yeni başlayan sosyal bilgiler öğretmenlerinin görüşleri, Cankır Karatekin Üniversitesi SBE Dergisi, 2(1): 157177.

TTK Türk Tarih Kurumu'nu taniyalım. Retrieved: 13.09.2015 from http://www.ttk.gov.tr

TTK Tarihçe. Retrieved: 13.09.2015 from http://tdk.gov.tr

Milli Tarih Öğretiminin Bazı Metodolojik Sorunları Retrieved: 13.09.2015 from http://ehistory.kz (b) $/ \mathrm{kz} /$ contents/view/1765. 